\title{
Omitted Variable Bias in the Link Between Planning and Performance
}

\author{
Kirk C. Heriot \\ Noel D. Campbell \\ R. Zachary Finney
}

\begin{abstract}
h his article argues that existing research poorly specifies the link between planning and performance because of omitted variable bias. Researchers agree planning is a critical part of creating any new venture. Many researchers assess planning by whether a small firm has a written business plan. Unfortunately, efforts empirically to validate this relationship have been inconclusive. This article proposes that researchers should assess business plans both on the quality of the plan (and the planning process that produced it), and on the quality of the underlying business opportunity. Failure to account for both aspects of a business plan amounts to omitted variable bias, frustrating attempts to accurately estimate the true relationship.
\end{abstract}

The business plan is commonly used as a factor for evaluating the relationship between firm planning and firm performance in small firms. Among the current models of entrepreneurship, many researchers have asserted a positive relationship between the use of formal planning and firm performance (see, e.g., Rue and Ibrahim 1998; Perry 2001; Fletcher and Harris 2002). Typically these models emphasize the use of written business plans (Rue and Ibrahim 1998; Sahlman 1997). However, the literature has not empirically demonstrated the expected relationship between formal planning (resulting in a written business plan) and firm performance in a consistent manner. In this article, we demonstrate the theoretical limitations of using business plans as a means of operationalizing formal planning in empirical research. Scholars frequently fail to properly account for multiple outcomes of the firm planning process, introducing omitted variable bias into their research.

We concur that a link probably exists between the use of written business plans by entrepreneurial firms and their subsequent performance (See e.g., Perry 2001; Fletcher and Harris 2002; Singhvi 2000; and Rue and Ibrahim 1998). We believe the tenuous nature of the empirical relationship may be explained from the perspective of both the content and the composition of the business plan (Trailer and Wolford 2001). The shortcoming from an empirical research perspective is the assumption that a written business plan represents good planning.That is, that the existence of a written business plan means that the principals in the entrepreneurial firm actually have engaged in planning, have produced a well-written and convincing business plan, have actually executed the plan, and that the perceived business opportunity was a tenable one.

In the next section, we review the literature. In the following section, we propose a model showing the situations that may be encountered when scholars operationalize planning through the use of business plans. We conclude by discussing the significance of this study for future empirical research.

\section{Literature Review}

Considerable research has evaluated the relationship between planning and firm performance, albeit usually in large organizations. However, more recent research has extended to small, entrepreneurial firms. Unfortunately, the small business findings are mixed. No clear picture of the relationship between formal planning and firm performance has emerged as various authors present conflicting findings. Some studies found a positive relationship (Perry 2001), while other studies have found a negative relationship (Hand, Sineath, and Howle 1987).Therefore, the impact of formal planning on performance is unclear.

Olson and Gough (2001) remark that problems begin with the different ways in which "formal planning" is defined. Further problems arise in the methods by which researchers operationalize formal planning. The most common method is to assess whether planning leads to a written document. Yet a written business plan may not be all that it appears to be. Sahlman argues that "the more elaborately crafted the document, the more likely the venture is to, well, flop, for lack of a more euphemistic word" (Sahlman 1997, p. 98).

The literature offers several explanations for the mixed results: differing definitions (Perry 2001), different means of operationalizing the construct (Olson and Gough 2001), and even questions over the extent to which business plans are actually produced by small businesses have been discussed (Parks, Olson, and Bokor, 1991). Sahlman (1997) suggests that entrepreneurs may be guilty of losing a theoretical perspective because their written plans reveal they do not have a business model that shows genuine insight into their perceived business opportunity. Hence, it is suspect whether many business plans have the proper perspective on what drives a par- 
ticular venture. Thus, we would not expect the written plan to be a good predictor of firm performance if it does not reveal insight into the business concept. The issue is further complicated because, as Pearce, Freeman, and Robinson (1987) remark, past studies do not appropriately control for other relevant variables such as leadership or competition.

Another common theme in the literature is the distinction between the business plan document created to direct an entrepreneurial/small business versus the process of planning. Many researchers are alarmed that too much emphasis is being placed on the business plan rather than the process that creates the plan (see, e.g., Robinson 1982; Hills 1985; Parks, Olson, and Bokor 1991; Trailer and Wolford 2001). Hills (1985) was among the first to question the significance of a written document. He asked venture capitalists to provide their expert assessment of the extent to which the business plans involved in-depth market information. Venture capitalists in his study believed that entrepreneurs ignore negative information. Thus, serious questions are raised about whether a business plan is truly representative of an adequate planning process. Other researchers concur, questioning whether written business plans actually represent good planning because of a variety of potential problems associated with either the opportunity expressed in the plan (Sahlman 1997) or the composition of the arguments (Trailer and Wolford 2001). Hall and Mestler point out, "If your business concept is untenable, no amount of assistance from business plan software will make it fly" (Hall and Mestler 1997, p.45).The implication is that knowing the elements of a business plan and producing a document are not enough.

Trailer and Wolford (2001) note that the literature has not emphasized actually writing a business plan despite the research identifying the steps, the elements, and factors critical to the written document.They argue that " $[\mathrm{m}]$ erely listing the important topics in a business plan creates only generalities. Details must support the arguments made about and for the topics... That is, effective business plans are the outcome not only of covering all the bases, but also of covering them well" (Trailer and Wolford 2001, p. 41). They go on to argue that entrepreneurs may have great difficulty composing meaningful business plans because of the intricacies of writing sound, complex arguments.

Ironically, despite these concerns, much of the empirical literature continues to emphasize a counting procedure whereby firms are categorized by whether they have a written plan (Olson and Gough 2001). Very little of the research makes an effort to evaluate the effectiveness of the written document in a substantive way, assuming that the presence of a business plans indicates the firm has actually engaged in planning. ${ }^{1}$

\section{An "Omitted Variable Bias" Schematic}

We have developed a schematic model expressing firms' potential outcomes expected upon analysis of the concept and composition of business plans. Although our model will be of limited use to practitioners, we hope the model proves useful to researchers in understanding the empirical difficulties linking business plans and firm performance. We suggest that business plans may be evaluated on at least two dimensions. Empirical failure to account for both dimensions amounts to omitted variable bias in one's estimates of the relationship between business plans and business performance. In the first of the two dimensions, the business concept may either be tenable or not tenable (i.e., the idea may have genuine commercial potential or it may not have commercial potential). Second, the plan may be either well written or poorly written. A well-written plan will be persuasive, consisting of a number of complex arguments that "produce strong conclusions regarding the feasibility of starting a business" (Trailer and Wolford 2001, p. 41). Our two dimensions led to a $2 \times 2$ model depicting four outcomes. Each cell in the model is associated with a different outcome (see Figure 1).

In the lower left-hand quadrant is a company with a written business plan in which the concept is untenable and the document has poor composition. This situation is clearly associated with negative firm performance. Yet, if researchers use written business plans as a measure of formal planning, this firm would be categorized with firms possessing well-written business plans supporting tenable (or even untenable) business concepts. Such data confusion is an example of omitted variable bias and will lead to inefficient empirical estimates.

The upper left-hand quadrant represents a poorly written business plan based on a tenable concept.The problem with this type of document is that it may not be able to engage the people in the firm (Carland and Carland 2003). As such, the document is not persuasive and does not capture the support of the firm's employees. Because the underlying business concept is good, the firm may succeed, but it will do so despite its business plan, rather than because of its business plan.

The lower right-hand quadrant is a firm that has written a convincing business plan for a concept that is simply untenable, a frequent occurrence according to Sahlman (1997). The entrepreneurs convince themselves that their idea will work and may even be able to put together a flashy document to support their concept. However, a persuasive document is no substitute for a plan to economically produce a good or service a customer base actually wants. Empirically, firms in this cell would produce a negative relationship between planning and performance. 


\begin{tabular}{|l|l|l|}
\hline $\begin{array}{l}\text { Business Plan } \\
\text { Is/Details: }\end{array}$ & \multicolumn{1}{|c|}{ Poorly Composed } & \multicolumn{1}{c|}{ Well Composed } \\
\hline A Tenable & $\begin{array}{l}\text { This type of business plan } \\
\text { may lead to positive firm } \\
\text { performance, but it may } \\
\text { overlook critical details due } \\
\text { to poor execution, leading to } \\
\text { implementation problems. } \\
\text { The firm may be successful } \\
\text { despite its business plan } \\
\text { rather than because of it. } \\
\text { "planning" } \rightarrow \text { poor } \\
\text { performance }\end{array}$ & $\begin{array}{l}\text { A good concept that is well } \\
\text { written is the most likely } \\
\text { situation whereby a written } \\
\text { business plan will be positive- } \\
\text { ly related to firm success. } \\
\text { This is what researchers } \\
\text { implicitly assume. However, } \\
\text { it is also only one of four } \\
\text { outcomes that may exist. } \\
\text { "planning" } \rightarrow \text { good } \\
\text { performance }\end{array}$ \\
\hline $\begin{array}{l}\text { An Untenable } \\
\text { Concept }\end{array}$ & $\begin{array}{l}\text { Despite the presence of a } \\
\text { written business plan, this } \\
\text { situation will be correlated } \\
\text { with poor firm performance. } \\
\text { "planning" } \rightarrow \text { poor } \\
\text { performance }\end{array}$ & $\begin{array}{l}\text { This type of business plan } \\
\text { looks good, but resembles } \\
\text { "lipstick on a pig." A well- } \\
\text { written plan is not a } \\
\text { substitute for a sound } \\
\text { concept. This situation } \\
\text { correlates with poor firm } \\
\text { performance. } \\
\text { "planning" } \rightarrow \text { poor } \\
\text { performance }\end{array}$ \\
\hline
\end{tabular}

\section{Figure 1. Omitted Variable Bias: The Empirical Relationship between Written Business Plans and Firm Performance}

In the upper right-hand quadrant of the model is a firm possessing a tenable business concept as documented in a well-composed business plan. This situation is what most researchers implicitly envision when they analyze the relationship between formal planning and firm performance. Such firms would produce an empirically significant, positive relationship between planning and performance. Unfortunately, this is an ideal situation for which there may not be many real-world examples.

Business plans are regularly evolving documents, so there can be some confusion as to what it means to "evaluate a business plan." However, for a plan to be effective it cannot change too rapidly or radically, or it loses its impact as a strategic document. Certainly, though, the literature evaluates plans and planning despite recognizing the ongoing process nature of both. Metaphorically, we can view evaluating a business plan as analyzing the occasional frame in a motion picture. Our schematic model is designed to demonstrate to scholars the potential source of omitted variable bias which has frustrated their empirical research. It will be of limited use, at best, for practitioners or consultants seeking to apply ex ante process control or ex post process analysis to a firm's planning.
This study has an important implication for future empirical research. The existing literature cannot seem to conclusively agree on the relationship between formal planning and firm performance. Our research suggests that we are placing far too much emphasis on the existence of a written plan, rather than on the content of the plan, whether planning was accomplished to write the plan, or the viability of the perceived business opportunity. The presumption that the mere presence of a business plan will lead to positive firm performance assumes that the business plan represents a good idea and that the plan has been well written. Our model suggests that at least three other outcomes are possible; it is these other outcomes that provide an explanation for the mixed results of empirical research. Firms with poorly written business plans and business plans based on untenable concepts-conditions expected to lead to poor firm outcomes-are empirically classified as having engaged in effective planning. Scholars should recognize that a richer means of assessing the relationship between planning and performance is needed, given the problems with traditional planning-performance research.

Unfortunately, discovering the existence of omitted variable bias is far easier than rectifying the problem. We believe we have identified the root problem that frustrates empirical researchers, but we have not solved it. Neither can a practitioner take our $2 \times 2$ schematic and produce a "can't fail" business plan nor assess the quality of her planning process. Our schematic indicates the need for empirical methods able to separate the quality of a business plan's arguments from the quality of the underlying business opportunity, ex ante. Therein lies the principal difficulty, as the most effective way of testing the quality of a perceived business opportunity is to observe the profitability of a firm organized to meet that perceived opportunity. Clearly, many market opportunities envisioned by entrepreneurs are, in reality, little more than wishful thinking. Yet the market is rife with examples of "bad ideas" that have become extraordinarily successful, such as Famous Amos and FedEx. This may be the true "omitted," unobservable, variable that has complicated researchers' estimations.

The presumption that the mere presence of a business plan will lead to positive firm performance assumes that the business plan represents a good idea which has been well written. Such a simplistic approach ignores the actual complexities: to be beneficial to a firm, its business plan must 
embody a sound business concept, and must be well written. These, along with a large portion of sheer luck and pockets full of capital, may be the bare essentials of a successful firm. Attempts at humor aside, there is no a priori reason to assume the mere existence of a business plan should be correlated with firm success. Failure to properly account for this complexity is one reason for the empirical difficulty linking business plans with firm success.

\section{Endnote}

1 However, Perry (2001) and Parks, Olson, and Bokor (1991) found that very few small firms actually create business plans. Carland and Carland (2003) suggest that evaluating entrepreneurs' use of business plans may be the wrong direction to go, as they question the extent to which entrepreneurs actually engage in this traditional form of planning.

\section{References}

Carland, JoAnn C., and James W. Carland. 2003. A Model of Entrepreneurial Planning and Its Effect on Performance. Retrieved February 16, 2003. (http://www.sbaer. 16 pages).

Fletcher, Margaret, and Simon Harris. 2002. Seven aspects of strategy formation. International Small Business Journal 20, 3 : 297-314.

Hall, Owen P., Jr., and Chad Mestler. 1997. Putting business planning software to the test. The Journal of Business Strategy 18, 1: $42-45$.

Hand, H.W., P. Sineath, and W.E. Howle. 1987. Small business concepts and their relationship to performance:A field study of retail service stations. Journal of Small Business Management 25, 2: 55-63.

Hills, Gerald E. 1985. Market analysis and the business plan: venture capitalists' perceptions. Journal of Small Business Management 23:38(9).

Olson, Philip D., and Newell Gough. 2001. Export Planning and Performance: An Organizational Culture Perspective on Small Firms. New England Journal of Entrepreneurship 4, 1:31-40.

Parks, B., P. D. Olson, and D. W. Bokor. 1991. Don't mistake business plans for planning (it may be dangerous to your financial health). Journal of Small Business Strategy 2, 1:15-24.

Pearce, J.A., E. B. Freeman, and R.B. Robinson. 1987. The tenuous link between formal strategic planning and financial performance. Academy of Management Review 12, 4: 658-675.

Perry, Stephen C. 2001. The relationship between written business plans and the failure of small businesses in the U.S.Journal of Small Business Management 39, 3: 201-208.

Rue, Leslie W., and Nabil A. Ibrahim. 1998. The relationship between planning sophistication and performance in small businesses. Journal of Small Business Management 36, 4: 24(9).

Robinson, R. R. 1982. The importance of 'outsiders' in small firm strategic planning. Academy of Management Journal 25, 1 : 80-93.

Sahlman, William A. 1997. How to write a great business plan. Harvard Business Review 75, 4:99-110.

Singhvi, Surendra S. 2000. Business planning practices in small size companies: Survey Results. The Journal of Business Forecasting Methods \& Systems 19, 2: 3-8.

Trailer, Jeff, and Chester Wolford. 2001. On the Logic of Business Plan Composition. New England Journal of Entrepreneurship 4, 1:41-50. 


\section{About the Authors}

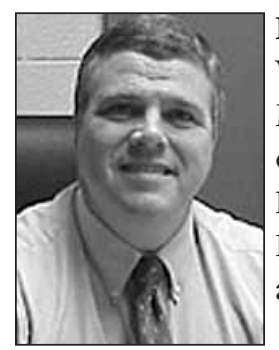

KIRK C. HERIOT (kirk.heriot@wku.edu) is an associate professor of management and entrepreneurship at Western Kentucky University. He earned his Ph.D. in industrial management with a concentration in Strategic Management at Clemson University in 1996. Dr. Heriot's research has been accepted for publication in numerous journals including the American Business Review, Journal of Supply Chain Management, Journal of Small Business Strategy, and Journal of Management Education. In 2004, Dr. Heriot and a colleague won the Distinguished Research Award at the Allied Academies Annual Conference. Dr. Heriot's primary area of scholarly research is entrepreneurship in challenging environments.

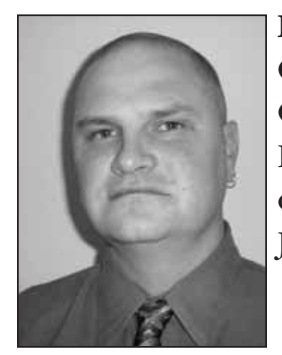

NOEL D. CAMPBELL (ndcampbell@ngcsu.edu) is an associate professor of business administration at North Georgia College \& State University. He earned his Ph.D. in economics at George Mason University in 1997. Dr. Campbell's research in economics has been accepted for publication in numerous journals including in the Eastern Economic Journal, Journal of Education Finance, and Public Finance Review. He has also collaborated on cross-disciplinary research that has been published in the Journal of Management Education and the Journal of Small Business Strategy. Dr. Campbell's primary area of scholarly research is public choice.

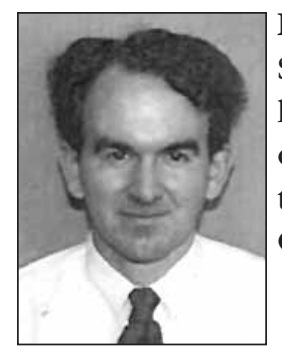

R. ZACHARY FINNEY (rzfinney@ngcsu.edu) is assistant professor of marketing at North Georgia College \& State University. He earned his Ph.D. in marketing from the University of Alabama in 2001. Dr. Finney's research has been accepted for publication in numerous journals including the Journal of Business Research, Journal of Management Education, and Marketing Management Journal. In 2003, Dr. Finney and two colleagues won the Steven J. Shaw Award for the Outstanding Conference Paper at the Society for Marketing Advances Annual Conference in New Orleans. Dr. Finney's primary area of scholarly research is marketing strategy. 